\title{
2 根障害を呈した遊走ヘルニアに対する内視鏡下手術の小経験
}

\author{
松山金寛* 田邊 史* 武富 栄 二* 石 堂 康 弘** \\ 山元 拓 哉** 井 尻幸 成** 米 和 徳** 小宮 節 郎**
}

\section{Microendoscopic Spinal Surgery for Extremely Migrated \\ Lumbar Disc Herniation with Bi-radicular lesion: A Report of Two Cases}

\begin{abstract}
Kanehiro Matsuyama*, Fumito Tanabe*, Eiji Taketomi*, Yasuhiro Ishidou**, Takuya Yamamoto**, Kosei Ijiri**, Kazunori Yone**, and Setsuro Komiya**
\end{abstract}

\begin{abstract}
腰椎椎間板へルニアに対する内視鏡下椎間板切除術は脊椎低侵襲手術とし本邦でも広く行われるように なってきた。我々は一椎体レベル以上遊走し 2 根障害をきたした腰椎椎間板ヘルニアの症例に対し，同一 皮切より 2 椎間鏡視を行いヘルニアを摘出，良好な成績を得た 2 例を経験した. 片側椎弓切除をせずとも 十分に除圧可能であり内視鏡下春椎手術は有用な術式であった.
\end{abstract}

Microendoscopic discectomy for lumbar disc herniation is a minimally invasive spinal surgery and used extensively. We endoscopically removed the herniated disc from two intervertebral sites through one skin portal in two cases of extremely migrated lumbar disc herniation with bi-radicular lesion. Both cases had a good outcome. Microendoscopic discectomy is less invasive and very useful for these cases.

Key words : microendoscopic discectomy (内視鏡下椎間板切除術), migrated lumbar disc herniation (遊走ヘルニア), bi-radicular lesion（2 根障害）

\section{は じめ に}

内視鏡下椎間板切除術 (microendoscopic discectomy；以下 MED）は 1996 年 Foley と Smith に より発表された ${ }^{1)}$. 本邦での MED による手術例は日 本内視鏡低侵襲脊椎外科学会の集計デー夕からみると, 2001 年には 863 例, 2003 年には 1,304 例であり, 2004 年に出沢により集められたデータでは, これま での全国の施行数は 8,675 例であった ${ }^{8)}$.このように MED は，近年ヘルニアに対する治療法の択肢として 広まりつつある. 当院で 2004 年より MED を導入し, 腰椎椎間板ヘルニアや一椎間の腰部脊柱管狭窄症に対 し内視鏡下脊椎手術を行ってきた。 今回，単一椎間板
のヘルニアが高度に一椎体レベル以上脊柱管内を遊走 し 2 根障害を呈した症例に対し, 一皮切より 2 椎間を 鏡視しヘルニアを摘出した症例を経験したので報告す る.

$$
\text { 症例 }
$$

【症例 1】50 歳, 男性, 消防士

主訴：左下肢痛, 歩行困難

現病歴：平成 18 年 12 月, 特に誘因なく左下肢痛が 出現した. 一時体動困難となったが, 安静にて軽快し た.しかし, 平成 19 年 1 月, 症状再燃した為近医を 受診したところ L3/4 の腰椎椎間板ヘルニアと診断さ れた. 左 L4 の選択的神経根ブロックを施行されたが,

\footnotetext{
* 鹿児島脊椎脊䯣研究班鹿児島赤十字病院整形外科 Department of Orthopaedic Surgery, Kagoshima Red Cross Hospital, Kagoshima, Japan

***鹿児島脊椎春䯣研究班鹿児島大学大学院運動機能修復学講座整形外科学 Department of Orthopaedic Surgery, Graduate School of Medical and Dental Sciences, Kagoshima University, Kagoshima, Japan
} 
左 L5 領域に疼痛が残存した。 その後症状増悪し左下 垂足が出現した為, 当科入院となつた.

理学所見: Kemp sign, SLR test, 大腿神経伸展 テストが左で陽性であり， MMT は左で膝の屈曲が (4), 足関節の底屈が $(3) \sim(4)$, 背屈が (3), 母趾の 背屈が（4）と低下が認められた. 知覚は, 左 L5 領 域で $7 / 10$ の知覚低下が認められた。膀胱直腸障害は なく, JOA スコアは 10/29 点（2-1-7-0）であった.

画像所見：単純レントゲンでは明らかな異常は認め られなかった. MRI では, L3/4 から突出し, L5 椎 体上縁まで左後方に連続するへルニアが認められた (図 1)。脊髄造影では，L4 椎体左側上縁より L4/5に かけて造影剤の欠損が認められ，CTM でも，同部位 に硬膜管の圧排が認められた（図 2).

また，左 L4 の選択的神経根ブロックに次いで，左 L5 の選択的神経根ブロックにより症状の改善が認め られ，L3/4 のヘルニアによる L4, L5 の 2 根障害と 診断した.

手術：同一皮切より 2 椎間を鏡視しヘルニア摘出術 を行った. ヘルニアが L $4 / 5$ まで高度に下垂していた

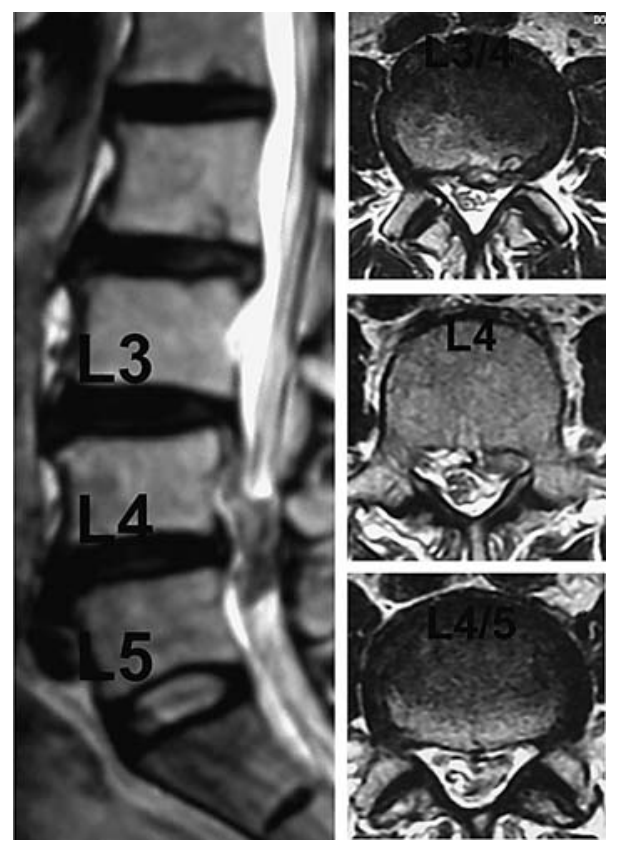

図 1 MRI (T2 強調像) L3/4 から突出し, L4 から L5 上縁の左後方に 連続する脱出ヘルニア
為, まず L4/5より鏡視し下垂したヘルニアを摘出し た. L4/5 の椎間板は軽度の膨隆は認めるものの L5 神経根の圧迫所見はなく, 脱出ヘルニアも認められな かった. 次に L3/4 より鏡視し残存したヘルニアを摘 出し, L4 神経根の圧迫が解除されたのを確認した.

術後経過：職場（消防士）復帰の為に十分な入院り ハビリを行いたいとの本人の希望があり, 術後約 1 ケ 月して退院し, 術後約 2 ケ月半で職場に復帰した. JOA スコアは術後約 5 ケ月の時点で $10 / 29$ 点から 27/29 点（9-5-13-0）に改善した.

【症例 2】 31 歳, 男性, 看護師 主訴：右下肢痛，歩行困難

現病歴：平成 18 年 10 月, 特に誘因なく右下肢痛が 出現した. 近医にて L4/5 の椎間板ヘルニアと診断さ れ，保存的加療を行い，症状は一時軽快傾向にあった が，11月中旬頃より右下垂足が出現した為，12月に 当科入院となった.
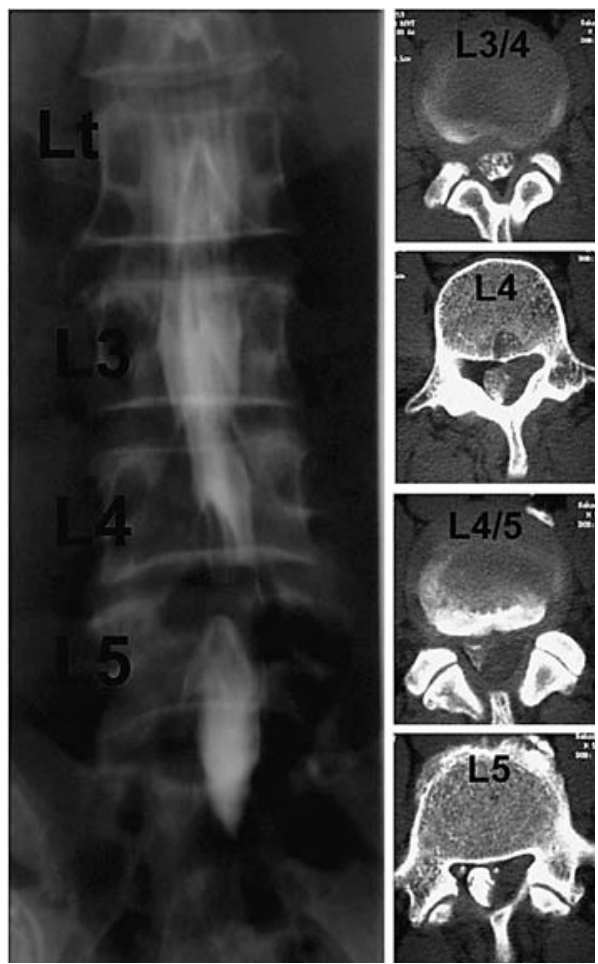

図 2 脊髄造影, CTM

春髄造影：L4 椎体左側上縁より L4/5 にかけ て造影剤の欠損 $(+)$ CTM : 同部位に硬膜管の圧排 $(+)$ 

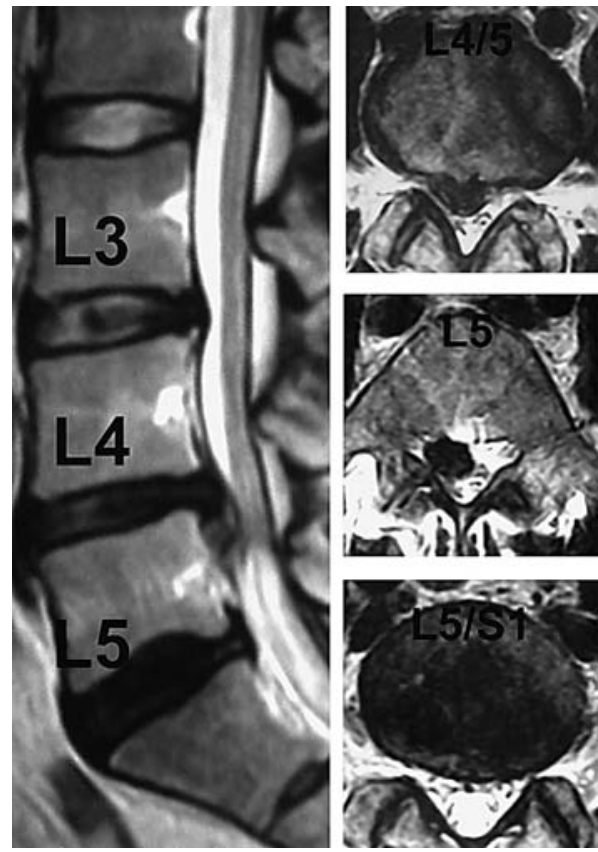

図 3 MRI（T2 強調像）

L4/5 より突出し, L5 から L5/S1 右後方に連 続する脱出ヘルニア

理学所見：SLR testが右で陽性. MMTは右で足 関節の底屈が (3)〜 (4), 背屈が (3), 母趾の背屈が （2）と低下が認められた．知覚は，右 L5, S1 領域で $5 / 10$ の知覚低下が認められた. 膀胱直腸障害はなく, JOA スコアは 15/29 点（4-1-10-0） であった.

画像所見：単純レントゲンでは明らかな異常は認め られなかった。 MRI では，L4/5 から突出し，L5か ら L5/S1 まで下垂し右後方に連続するへルニアが認 められた（図 3)。春髄造影では，L4/5 右外側に造影 剤の欠損が認められ，CTM でも，同部位に硬膜管の 圧排, 及び右 $\mathrm{S} 1$ 神経根囊像の欠損が認められた（図 4).また, 右 L5 の選択的神経根ブロックにより症状 の改善が認められたが, 神経学的に S1 神経根症状も あり，L4/5から下垂したヘルニアによる L5, S1の 2 根障害と診断した.

手術：同一皮切より 2 椎間を鏡視しヘルニア摘出術 を行った。まず，L4/5 より鏡視すると L 5 神経根の 腋の部分より膨隆したヘルニアが確認され，これを摘 出した. 次に, L5/S1 より鏡視した. L5/S1 のヘル ニアは認めず, 頭側より下垂したヘルニアを摘出し,

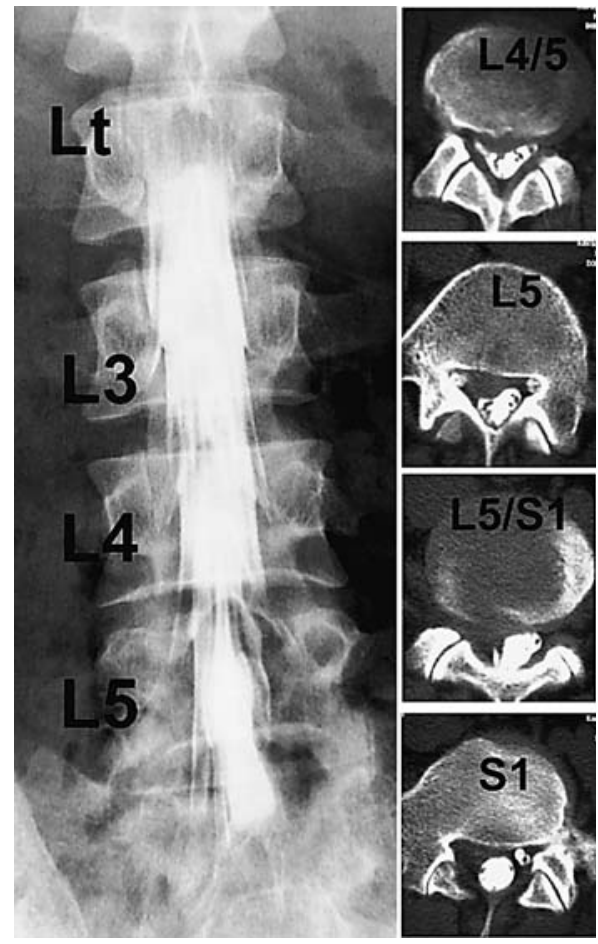

図 4 春髄造影, CTM

脊髄造影：L4 椎体左側上縁より L4/5 にかけ て造影剤の欠損 $(+)$

$\mathrm{CTM}$ ：同部位に硬膜管の圧排，及び右 $\mathrm{S} 1$ 神経 根囊像の欠損 $(+)$

$\mathrm{S} 1$ 神経根の圧迫が解除されたのを確認した.

術後経過：術後特に合併症なく, 1 週間で退院し, 約 2 ケ月で職場に復帰した. JOA スコアは術後約半 年の時点で $15 / 29$ 点から $24 / 29$ 点 (8-3-13-0) に改善 した.

考察

単一椎間の腰椎椎間板ヘルニアによる 2 根障害例と して, ヘルニアが椎間板レベルより頭側あるいは尾側 への脱出 ${ }^{55)}$, 同一椎間での椎間孔内と春柱管内ヘルニ アの合併 ${ }^{2336)}$, 同一椎間での椎間孔外と脊柱管内ヘル 二アの合併 ${ }^{677)}$, 神経根奇形 ${ }^{4)}$, などが報告されている. 症状としては, 高度の筋力低下（下垂足を含む）や膀 胱直腸障害を来たす事が多い.今回の症例は，いずれ もヘルニアが椎間板レベルより脊柱管内を尾側に一椎 間以上遊走した結果， 2 根障害を来たし下垂足を呈し 
ていた.

これまではこのような高度に遊走したヘルニアでは, 治療法として, open surgeryにて 2 椎間の部分椎弓 切除術や片側椎弓切除などを行ってきたが，今回，同 一皮切より 2 椎間を鏡視しヘルニア摘出を行った. 片 側椎弓切除せずともへルニアが十分摘出でき, 神経根 の確認も可能であつた. これは斜視鏡であることが有 利に働いていると考えられた。 今回，合併症もなく， 術後成績も良好であり, このように高度遊走したヘル ニアでも MED は低侵襲手術として非常に有用であっ た.

$$
\text { 結語 }
$$

2 椎間障害を呈した遊走ヘルニアに対し, 内視鏡下 椎間板切除術は有用な術式の 1 つであった.

\section{参 考 文 献}

1) Foley, K. T., Smith, M. M.: Microendoscopic Discectomy. Techniques in Neurosurgery, $3: 301$ 307, 1997.

2) 糸井 陽ら : 2 根障害を生じた単椎間の腰椎椎間板へ ルニアに対し，内視鏡下にヘルニア摘出を行った 1 例. 東日整災外会誌, $17: 513,2005$.

3）森田裕己ら : 2 根障害を呈した腰椎椎間板ヘルニアの 検討. 東日整災外会誌, $10: 328,1998$.

4）仲井間憲彦ら：神経根奇形により片側 2 根障害を呈し た腰椎椎間板ヘルニアに対し内視鏡で髄核摘出を行った 1 例. 整形外科, $56: 150-152,2005$.

5）梁 昌鳳ら：椎体後面に脱出した腰椎椎間板ヘルニア の臨床像. 臨整外, 31:593-598, 1996.

6) 種市 洋ら : 単一椎間の腰椎椎間板ヘルニアによる 2 根障害例の検討. 日脊椎外会誌, $4: 56,1993$.

7）種市 洋ら：2 根障害をきたす特殊な腰椎椎間板へル 二ア. 臨整外, $29:$ 949-954, 1994.

8）吉田宗人：内視鏡下春椎手術の適応と限界. 関節外科, $25: 16-19,2006$. 